\title{
Climate Change as a I Disrupter of the Notion of Border in International Law
}

\author{
Pau de VÍlCIIEZ MOR MGUES
}

\begin{abstract}
4bstract: Due to its global nature and effects, climate change is generating considerable tension in several fundamental concepts and principles of public international law, such as the principles of no harm and prevention, human rights, or the very phy sical basis on which the concept of territorial sovereignty is grounded. At a time when the fragility of the natural systems on which human civilization as we know it is based is becoming increasingly evident, with devastating consequences, International law must adopt an eco-centric perspective that enables it to move beyond the traditional State-centric vision, which is proving unable to provide solutions to the almost existential challenges of an era that some are already beginning to call the Anthropocene.
\end{abstract}

Kevwords: climate change, border, jurisdiction, climate litigation, human rights, sovereignty, migration, Anthropocene.

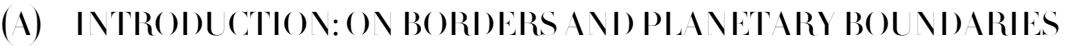

Since the Peace of Westphalia in the $7^{\text {th }}$ century and the emergence of modern international law, States have been the basis of the international legal sy stem.' The nature of States as the fundamental subjects of international relations and, especially, of international law was maintained with the advent of contemporary international law, although during this period the international legal system has had to begin to adapt to the emergence of relations of interdependence due, amongst other things, to increased trade, communications and energy flows. ${ }^{2}$

However, climate change and the serious environmental crisis that the planet is experiencing —which has received an increasing altention from the international community, especially since the r972 Stockholm Conference on the Ituman Environment ${ }^{3}$ — are highlighting just how dependent human beings are on the natural environment. Litlle by little, in ternational law has sought to develop mechanisms and concepts to reflect this new concern and facilitate adequate protection of these new legal rights. In the I97os, notions such as "common heritage of humankind”’ or "common concern of humankind”began to

a Irlicle published on.31 December 2org.

Assistant Lecturer (Profesor tyudanle) of Public International Law, University of the Balearic Islands (UIB), and Deputy Director of the Interdisciplinary Lab on Climate Change of the L niversity of the Balearic Islands (LI\CC UIB), pau.devilchez ${ }^{a}$ uil.en. This article largely reproduces the paper of the same title presented at the Jean Vonnet- VEPIDIRI International Conference 'La Unión Europea y los Vuros Materiales e Inmateriales: Desafíos para la Seguridad, la Sostenibilidad y el Estado de Derecho' The European Union and Tangible and Intangible Walls: Challenges for Security, Sustainability and the Rule of Lawp, held on 29 and $3^{\circ}$ Vay 2019 on the L niversity of Castilla-La Vancha's Cuenca campus.

V. Iíez de Velasco, Instiluciones de Derecho Inlernacional Prúblico (Tecnos, Vadrid, 2013), at 63-65, 282-28 1.

$2 \quad$ Ibid., at $67-68$.

3 U $\backslash$ General Assembly, Uniled Nations Conference on the I/uman Environment, 15 December 1972, I RES 2994.

4 A.-C. Kiss, 'La Yotion de Patrimoine Commun de l'I lumanité, ${ }_{75}$ Recueil des Cours (Académie de Droil International, The Ilague, 1982).

5 The U Y General Assembly considered climate change a "common concern for humankind" as early as 1988 (UY General Assembly Resolution 43.53 on the protection of the global climate for present and future generations of mankind, $\mathrm{U}$ I 
take shape, whilst principles such as those of prevention, ${ }^{6}$ precaution ${ }^{7}$ or sustainable development ${ }^{8}$ began to be articulated in the context of regimes such as the law of the sea ${ }^{9}$ or the protection of the atmosphere."

Since then, successive scientific studies on the environmental impact of the current economic system of mass production and consumption, as exemplified by the May 2019 Intergovernmental Science-Policy Platform for Biodiversity and Ecosystem Services (IPBES) report, "have revealed a hitherto often disregarded level of interdependence between species and ecosystems. It is therefore encouraging that such interdependence is being increasingly reflected in recent international case law.'2

Climate change is one of the main challenges facing humankind, as highlighted by leading international organizations. ${ }^{3}$ Ilowever, as the aforementioned IPBES study shows, it is not the only serious environmental problem we have to contend with. That is why the scientific community increasingly refers to the notion of global change, taking into account all the impacts of human activity at multiple levels on the natural environment.' Another recent concept is that of planelary boundaries, developed to illustrate the natural limits within which human life as we know it can thrive and which

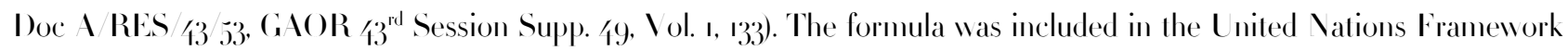
Convention on Climate Change (at recital one) (United Vations Framework Convention on Climate Change, 9 May 1992, 177ı U NTS 107 (U NFCCC)). See also: I. Feichtner, 'Community interest', in Max Planck Encyclopedia of Inlernalional Law (electronic edition, O\ford U niversity Press, 2007), accessed on g.July 2019.

6 L.- I. Duvic Paoli, 'Principle 2: Prevention', inJ.E. Viñuales (ed), The Rio Declaration on Environment and Developmenl: A Commenlary (Oxford University Press, 201 $)$ ).

7 A. A. Cançado Trindade, 'Principle ıу: Precaulion', in The Rio Declaration on Environment and Development: 1 Commenlary, supra n. 6.

8 V. Barral and P.- I. Dupuy, 'Principle a: Sustainable Development through Integration', in The Rio Deckaration on Environment and Development: 1 Commenlarv, supra n. 6.

9 Article 136 of the $\mathrm{X}$ General Assembly Convention on the Law of the Sea, so December ig82, 1833 U VTS 397.

10 Vienna Convention for the Protection of the Ozone Layer, 153 U VTS 323; 26 IL M 1529 (1987).

" E.S. Brondizioel al. (eds), Global assessment report on biodiversity and ecosyslem services of Ihe Inlergovernmenlal Science-Policy Plalform on Biodiversily and Ecosyslem Services (IPBES Secretariat, Bonn, Germany, 2019).

12 In this regard, the Inter- American Court of Iluman Rights' 2017 Adisory Opinion on the environment and human rights is particularly important. In it the Court held, "The Court considers it important to stress that, as an autonomous right, the right to a healthy environment, unlike other rights, protects the components of the environment, such as forests, rivers and seas, as legal interests in themselves, even in the absence of the certainty or evidence of a risk to individuals. This means that it protects nature and the environment, not onl because of the benefits they provide to humanity or the effects that their degradation mas have on other human rights, such as health, life or personal integrity, but because of their importance to the other living organisms with which we share the planet that also merit protection in their own right." Inter- American Court of Ituman Rights, Environment and IIuman Rights (State obligations in relation to the environment in the context of the protection and guarantee of the rights to life and to personal integrity: interpretation and scope of Articles $\mathbf{f}_{(\mathrm{I})}$ and $\mathrm{j}_{\mathrm{I}} \mathrm{I}$ ) in relation to Articles I(I) and 2 of the American Convention on I tuman Rights), A wisory Opinion OC-23 17 of 15 Vovember 2or 7 , Series 1 \o. 23 , at \$62.

3 On to September 2018, the U I Secretary General, Antonio Guterres, gave a speech on climate change with the following introductory remarks: "Dear friends of planet Earth. Thank you for coming to the U I Headquarters todas. I have asked you here to sound the alarm. Climate change is the defining issue of our time - and we are at a defining moment. We face a direct existential threat." Secrelarv-General's remarks on Climale Change, United Vations Secretary General, ı September 2018.

'‘ C.M. Duarte el al., Cambio global: impaclo de la actividad humana sobre el sislema Tierra ( Los Libros de la Catarata, Madrid, 2009). 
underscores just how close we are as a species to exceeding them. ${ }^{5}$ In fact, given the severity of the situation, more than a few voices have raised to propose a change in terminology that would more accurately reflect the serious threat looming over us. Rather than climale change, they suggest, it would be more appropriate to refer to the climale crisis (as the British newspaper The Guardian recently noted in its style guide).' ${ }^{6}$ Likewise, rather than a global change, one could speak of a global (environmental) crisis.

In any case, climate change, or the climate crisis, is deeply interconnected with many of the aforementioned planetary boundaries. It thus perfectly illustrates the extent to which the idea of an international law organized primarily around state sovereignty - one of the essential manifestations of which is the notion of borders, insofar as they define the space within which each State may exercise its prerogatives free of interference has significant shortcomings when it comes to tackling the challenges facing humankind in an era so shaped by human aclivity that it mav even give rise to a new geological age, i.e. the Anthropocene. ${ }^{17}$

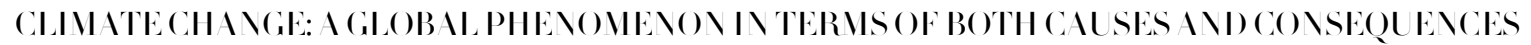

Current global warming, caused by the accumulation of mainly anthropogenic greenhouse gas emissions, is a major challenge for the international community. Climate change is not a traditional environmental risk with a geographically limited origin and impact, such as river pollution or the loss of a given habitat. Instead, it has an undeniable global dimension. For one thing, it is caused by all the greenhouse gas emissions emitted throughout the world as a whole. For another, its impacts are already being felt around the planet, irrespective of borders. Furthermore, climate change exacerbates many other existing environmental problems, both global and local in scope, such as desertification, reduced availability of drinking water, the loss of biodiversity and ocean acidification, amongst others.

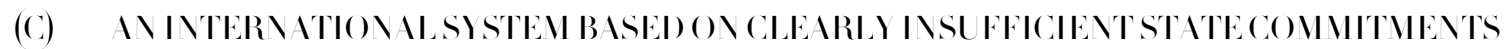

This poses a considerable challenge when it comes to organizing an effective response to climate change, as no amount of reductions in a single country's greenhouse gas emissions, no matler how large, can suffice to prevent global warming or even its consequences for that country. Therefore, any suitable response to global warming will require the consensus of the majority of States, which goes beyond purely state-based visions and interests. Accordingly, the phenomenon has been addressed in numerous international forums, especially those sponsored by the United Xations, where an international system has been set up over the last three decades, organized around the 1992 United \ations Framework Convention on Climate Change

\footnotetext{
i5 II. Steffen el al., 'Planetary boundaries: Guiding human development on a changing planet', 3 亿7 (6223) Science

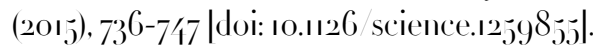

16 D. Carrington, 'Wh the Guardian is changing the language it uses about the environment', The Guardian, 17 May 2019.

17 W. Steffen el al., "The Anthropocene: Conceptual and historical perspectives', 369 1938 Philosophical Transactions of the Royal Sociely (2011) 8 /2 |doi: 10.1098 rsta.2010.0327|.
} 
(U NFCCC), ${ }^{8}$ with the wo major milestones of the Kyoto Protocol of $1997^{19}$ and, much more recently, the Paris Agreement, adopted in $2015 .{ }^{20}$

The Kyoto Protocol included a global vision that translated to clear and specific obligations for the different states (at least for those states listed in Annex B of the Protocol, which are largely the same ones as those listed in Annex I of the U NFCCC). Ilowever, the wariness that many countries (the United States, Russia, Canada, etc. 2t felt towards this approach significantly limited the Protocol's impact. As a result, the international community tried a different strategy with the Paris Agreement. ${ }^{22}$ That Agreement defines a system based on voluntary contributions defined by the States parties themselves (the so-called Xationally Determined Contributions or NDCs), which are to be periodically revised to incorporate increasingly ambitious targets for the reduction of greenhouse gas emissions. ${ }^{23}$ However, whilst this strategy resulted in near-universal ratification of the Agreement in record time (in fact, the Paris Agreement entered into force almost one year sooner than originally anticipated), ${ }^{21}$ the scientific community constantly recalls that the sum total of the voluntary commitments presented by the States parties is wholly insufficient to achieve the temperature targets set in the Agreement itself, namely: "Itolding the increase in the global average temperature to well below 2 C above pre-industrial levels and pursuing efforts to limit the temperature increase to 1.5 C above pre-industrial levels". ${ }^{25}$ Furthermore, many States are not even on track to reduce

18 Supra n. 5 .

19 Protocol to the United Nations Framework Convention on Climate Change, Ky oto, It December 1997, 2303 U VTS I/48 (Kvoto Protocol).

20 U VFCCC, Decision a CP.21, Adoption of the Paris Agreement FCCC CP/2015 10 /dd...

${ }_{21}$ The United States never ratified the Kyoto Protocol, Canada notified its withdrawal from the Protocol on ${ }_{5 j}$ December 2011, and neither Russia nor Japan have committed to the Protocol's second commitment period, agreed in Doha in 2012 (Doha amendment to the Kvoto Protocol, 28 February 2013, FCCC KP CVIP/2012/3/3 Add., Decision i CVIP.8). See: L. Rajamani, 'The United Vations Framework Convention on Climate Change: a framework approach to climate change', in D. A. Farber and V. Peeters (eds), Climale Change Law, Elgar Encyclopedia of Environmental Law (Elgar, Cheltenham, 2016). On the Canadian government's notification, see United Yations Trealy Collection, Chapter XXVII Emvironment, 7. a Kvoto Prolocol to the I nited Xations Framework Consention on Climate Change.

${ }_{22}$ J.E. Vinuales, The Paris Climate Igreement: An Initial Evamination', 6 C-EE VRG II orking Papers (2015); P. de Vilchez Moragues, The Paris Agreement: I Significant Vew Thread in the Legal Tapestry of Climate Change Domestic Litigation', in C.Cournil and L. V arison (eds), Les ProcèsC Climaliques. Entre le National et l'Inlernational (Pedone, Paris, 2018), at $/ 7-5^{0}$. For a more detailed account of the negotiating process, refer to: J. Bulmer, V. Doelle and D. Klein, 'Yegotiating Ilistory of the Paris Agreement', in D. Klein el al. (eds), The Paris Agreement on Climale Change: Analysis and Commentary (O)ford University Press, Oxford, 2017) 50-73.

23 Article f., supra n. 20.

24 The Agreement was adopted on 12 December 2015 . Less than one year later, on 5 October 2016 , more than 55 countries accounting for more than $55^{\circ} \%$ of global GllGe emissions had ratified it, allowing it to enter into force zo dav s later, in accordance with Article 21(t) of the Agreement, making it one of the fastest ratification processes of a multilateral en ironmental treaty. See

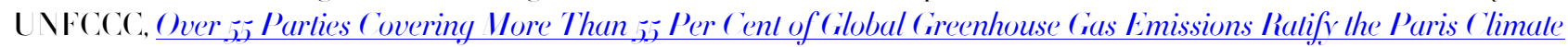
Change Igreement, 5 October 2016.

${ }_{25}$ Article 2.I.(a) of the Paris Agreement, supra n. 20. As regularly underscored by the U NEP, in its yearly "Emissions Gap Report". According to its latest report, published in November 2018, "Current commitments expressed in the NDCs are inadequate to bridge the emissions gap in 2030. Technically, it is still possible to bridge the gap to ensure global warming stars well below 2 C and $\mathrm{I}_{.5}$ C, but if XDC ambitions are not increased before 2030 , exceeding the $1_{. j}$ C goal can no longer be avoided. Jow more than ever, unprecedented and urgent action is required by all nations. The assessment of ac lions by the Geo countries indicates that this is yet to happen; in fact, global $\mathrm{CO}_{2}$ emissions increased in 2017 after three years of stagnation." U VEP, The Emissions Gap Reporloor8. Eveculive Summary, at 4. This gap had already been included in Article s7 of the Decision i CP.21 
their emissions enough to meet the commitments they have voluntarily undertaken. ${ }^{26}$ In this regard, it is worth asking whether a system built on a State-based approach, one that depends on the (good) will of States, is indeed the most suitable one to solve a global problem requiring global action.

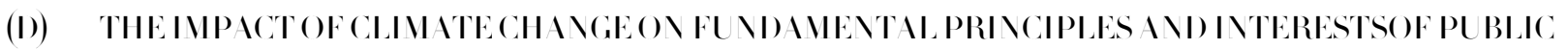

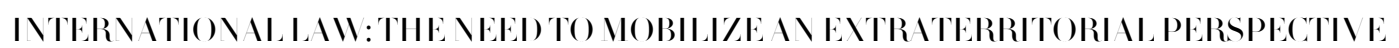

\section{(I) Principles of International Law}

Given that neither the causes nor the consequences of climate change heed borders, it seems essential, from an international law perspective, to refer to those principles of a markedly cross-border nature. One key principle in this regard is the no-harm rule. Closely linked to the principles of good neighbourliness and the sovereign equality of States, it requires States to refrain from engaging in activities in their territory that might harm the territory of another State. ${ }^{27}$ Beginning in the 1960 , as a result of the improved understanding of the relationships between ecosvstems and the close connection between human beings and natural processes, the concept evolved also to encompass the protection of areas not under the territorial sovereignty of any state, thereby giving rise to the prevention principle. ${ }^{28}$ This principle was included in the Stockholm Declaration on the I Iuman Environment (Principle 21) in 1972.9 and, Iwenty years later, in the Rio Declaration on the Environment and Development (Principle 2).30 It should thus come as no surprise that the U NFCCC of 1992 made specific reference to prevention in both Article 2 , defining the Convention's objective, and Article 3 , on the principles to guide States' actions to achieve that objective. ${ }^{3}$ Underscoring the supranational dimension of global warming, the UNFCCC moreover

adopting the Paris Agreement, which emphatically states that the Conference of Parties "Voles with concern that the estimated aggregate greenhouse gas emission levels in 2025 and 2030 resulting from the intended nationally determined contributions do not fall within least-cost 2 C scenarios but rather lead to a projected level of 5.5 gigatonnes in 2030 , and also noles that much greater emission reduction efforts will be required than those associated with the intended nationally determined contributions in order to hold the increase in the global average temperature to betow $2 \mathrm{C}$ above pre-industrial levels by reducing emissions

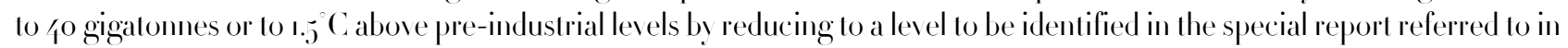
paragraph 2 below".

26 According to Climate Action Tracker, which anals ses both countries' current policies and their medium- and long-term commitments, only seven countries in the world are implementing policies compatible with an increase in the global temperature of less than $2 \mathrm{C}$, whilst onl two are implementing climate policies compatible with the target set in the Paris Igreement. See the analysis published by Climate Action Tracker at: hillps: climateactiontracker.org countries. According to the scientific consortium's anals sis, which is available on its website, amongst the industrialized countries, which have contributed most to climate change, the policies defined by Canada or Australia, amongst others, are not consistent with the targets thev themselves set in their respective NDCs.

${ }_{27}$ J. Brunnée, 'Sic uteretuoutalienum non laedas', in Max Planck Encyclopedia of Public Inlernational Law (Oxford Universily Press, 2010).

28 Supra n. 6.

29 Declaration of the United Nations Conference on the Iluman Environment, Stockholm, I6 June 1972, U \ DIC. $\triangle$ CONF 48 1/4 Rev. ('Stockholm Declaration').

30 Rio Declaration on Environment and Development, 13. June 1992, U \ Doc. A CONF.151/26.Rev. ( Rio Declaration').

${ }_{31}$ Article 2 states, "The ultimate objective of this Convention and anv related legal instruments that the Conference of the Parties may adopt is to achieve, in accordance with the relevant provisions of the Convention, stabilization of greenhouse gas concentrations in the atmosphere at a level that would prevent dangerous anthropogenic interference with the climate system." 
explicitly refers to climate change as a common concern of humankind, a formulation that was also incorporated into the $205_{5}$ Paris Agreement..32

However, the extraterritorial ramifications of climate change go even further, making it possible to deepen the cross-border protection of other fundamental legal goods.

(2) Extraterritorial Application of Iluman Rights

A country's $\mathrm{CO}_{2}$ and other greenhouse gas emissions contribute to global warming throughout the planet, and the effects of that global warming will be all the more serious the greater the atmospheric concentration of those gases. The literature on the impacts of climate change is extensive. One factor that no one seems to dispute is that the phy sical impacts of, or the impacts exacerbated by, climate change (such as extreme weather phenomena, rising sea levels, ocean acidification, heat waves or droughts) will have serious consequences for the human rights of the people subjected to them. Fundamental rights, recognized in both international, regional and domestic instruments, such as the rights to life, physical integrity and health, family and private life, food, drinking water, culture, property or even selfdetermination, will be seriously affected by climate change. ${ }^{33}$ Furthermore, as noted, due to how the physical mechanisms responsible for global warming work, a country's greenhouse gas emissions will not affect only its own inhabitants, but rather will join the rest of the emissions present in the atmosphere, thereby contributing to generate impacts anwwhere on the planet. To make matters worse, both the Intergovernmental Panel on Climate Change (IPCC) reports ${ }^{31}$ and those of many other scientific institutions warn that the countries least responsible for climate change will be the ones most affected by its impacts, which adds a serious issue of fairness to the problem of human rights.3.

Article 3 provides, "The Parties should take precautionars measures to anticipate, prevent or minimize the causes of climate change and mitigate its adverse effects." Supra n. I8. Notwithstanding the reference to the prevention principle in the core instrument regulating climate action at the international level, it is remarkable that this principle as well as other key principles in environmental law, such as the precautionary principle, which was also set forth in Article 3 of the Framework Convention, are completelv absent from more recent climate change instruments, such as the Kyoto Protocol or the Paris Agreement.

$3^{2}$ Recital of the U NFCCC reads, "Acknow ledging that change in the Earth's climate and its adverse effects are a common concern of humankind", whilst Recital u of the Paris Agreement acknowledges "that climate change is a common concern of humankind". Supra n. 20.

33 O. Quirico and M. Boumghar (eds), Climale Change and Iluman Righls: In Inlernational and Comparative Law Perspective (Routledge, Oxon, 2016). The Ituman Rights Council and other human rights bodies have also dealt with the question, pointing out the human rights implications of climate change and how human rights should be integrated in the response to global warming in order to achieve a better outcome. See, for instance: Report of the Office of the I niled Valions IIigh Commissioner for IIuman Rights on the relalionship belween climale change and human rights, U V DOc. I IIRC. IO 6I, ${ }_{5}$ January 2oog; and Reporl of the Special Rapporteur on the issue of Iluman Rights Obligations Relating lo the Enjoyment of a Safe, Clean, Ileallhy and Suslainable Environment: Climale Change Reporl, U X Doc. I IIRC 31 j2, I February 2016.

34 The Intergovernmental Panel on Climate Change (IPCC) is the scientific advisors bods created by the Morld Meteorological Organization and U VEP in 1988 to regularly assess the scientific knowledge on climate change. The IPCC reports reflect the highest degree of scientific and political consensus on global warming. They can all be found on the IPCC's web page.

35 "Climate change will amplify existing risks and create new risks for natural and human svstems. Risks are unevenly distributed and are generally greater for disadvantaged people and communities in countries at all levels of development"; 
In this regard, it is interesting to note that some regional human rights sy stems have clearly affirmed the extraterritorial nature of state jurisdiction when acts committed in the territory of a State negatively impact the human rights of people located beyond its borders..$^{6}$ Even more interestingly, some regional human rights instruments have clearly recognized this extraterritorial nature of State jurisdiction when the actions or onissions of a State result in environmental degradation in a third state that interferes with the ability of persons in that third State to enjoy their human rights. In this regard, the Inter- Imerican Court of Human Rights' Advisory Opinion of Xovember 2017 is especially notable, as it analy ses the links between respect for the environment and the enjoyment of human rights. In the Opinion, the Court states that there is an "undeniable relationship between the protection of the environment and the realization of other human rights, in that environmental degradation and the adverse effects of climate change affect the real enjoyment of human rights". It concludes that "to ensure the rights to life and integrity, States have the obligation to prevent significant environmental damage within and outside their territory" ${ }^{37}$

In a world in which just five countries are responsible for almost $60 \%$ of global greenhouse gas emissions $^{3^{8}}$ emissions that are already having serious impacts around the planet that will only grow exponentially if the Paris Agreement targets ${ }^{39}$ are missed — it seems clear that the principles of no-harm and prevention are being violated and that these countries are impacting the current and future enjoyment of the human rights of persons living not only within their own borders, but also in any other country in the

\footnotetext{
"Mitigation and adaptation raise issues of equity, justice and fairness. Many of those most vulnerable to climate change have contributed and contribute little to GIIG emissions"; "Climate change exacerbates other threats to social and natural sy stems, placing additional burdens particularly on the poor (high confidence)". R.K. Pachauri and L. I. Meyer (eds), Climale Change 201/: Synthesis Report. Contribution of II orking Groups I, II and III to the Fifih Assessment Report of Ihe Inlergovernmenlal Panel on Climale Change (IPCC, Geneva, Swilzerland, 201/1), al 13, 17 and 31.

$3^{6} \quad$ For instance, Loizidouv. Turkey, ECIIR (1995) \} \searrow _ { 0 . 1 5 3 } 8 \text { 89; Al-Skeini and others v. The U nited Kingdom, ECIIR (2011) } \o. 5.5721 o7; or Catan and others v. the Republic of Moldova and Russia, ECIIR (2012) \o. 13370/0/.

37 Supra n. 12, at $\$$ 彳 and $\$ 2$ 2. Other passages of the ad isory opinion, in which the Court examines the extraterritorial dimension of States' obligations concerning human rights and the environment in detail, are likewise of great interest. See, for instance, the following wo: "\$ 59 In its collective dimension, the right to a healthy environment constitutes a universal value that is owed to both present and future generations. (...) a heallhy environment is a fundamenlal right for the exislence of humankind" (emphasis added); and " $\$$ IOI (...) when transboundary damage occurs that affects treaty-based rights, it is understood that the persons whose rights have been violated are under the jurisdiction of the State of origin, if there is a causal link between the act that originated in its territory and the infringement of the human rights of persons outside its territory."

$3^{8}$ According to data from EIAGR (Emission Database for Global Almospheric Research), a European Commission initiative, these countries are China, the United States, India, Russia and Japan. If the European Union as a whole were counted as a country, it would be the third largest greenhouse gas emitter and, in all, the top five emitters would account for two thirds of global emissions. Itowever, when the list is compiled based strictly on countries, the only EU country in the top ten emitters is Germany, which ranks sixth. When historical emissions, rather than just current ones, are used, the results in terms of the main emilting countries are quite similar. To give an idea of the extent to which emissions are concentrated in a minority of countries,

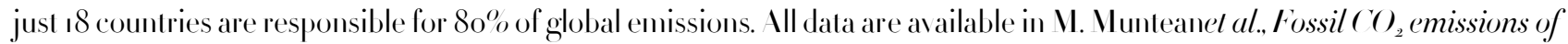
all world countries - 2018 Report, EUR 29/33 EV (Publications Office of the European Union, Luxembourg, 2018) |doi: 10.2760 30158, JRCir3738|.

39 See, for example, the IPCC report published in October 2018, which compares the different consequences of global warming of $1.5^{\circ}$ C versus $2^{\circ}$ C. IPCC, 'Summary for Policymakers', in V. Masson-Delmotteel al. (eds), Global warming of 1.5 C: In IPCC Special Report on the impacts of global warming of s.j C above pre-industrial levels and relaled global greenhouse gas emission palhways, in the conlext of strenglhening the global response to the threat of climale change, sustainable development, and efforls to eradicale poverty (World Meteorological Organization, Geneva, Switzerland, 2018).
} 
world. Given this situation, the position taken by the Inter- American Court of Ituman Rights in its 2or7 Advisory Opinion seems highly relevant. It remains to be seen whether the international or regional human rights protection mechanisms will be willing to apply such a perspective in cases calling for States to be held responsible for climate change, with the potentially ensuing consequences. To date, no judgment or decision delivered at the supranational level has examined the merits of the matter. ${ }^{\circ}$ In contrast, a growing number of national courts judgments have recognized that the action or inaction of the respective government regarding climate change is causing or will cause serious harm to the plaintiffs' human rights. Ilowever, although the extraterritorial question has been raised in some of these cases, the courts involved have thus far preferred to leave it unanswered.'

\section{(3) When Climate Change Threatens the Physical Existence of a State Itself}

One of the main impacts of global warming is rising sea levels, which, if the increase in the global temperature is not contained, could cause the virtual disappearance of some low-lying Pacific island States. ${ }^{2}$ The potential impact of climate change on the principle of State sovereignty and the right to selfdetermination is thus difficult to overstate. That is why, in parallel with an intensive diplomatic activity in

10 Within the scope of the European Union, in 2018, several families from various EU countries, Kenya and the Fiji Islands brought an action before the EU Court of Justice against EU regulations on fighting climate change arguing that they violate higher-order EU laws, the U NFCCC and the Paris Agreement, as well as based on torto law considerations. In May 2org, the EU General Court dismissed the case without ruling on the merits, due to the plaintiffs' lack of standing. Also in the month of May, a group of Torres Strait islanders lodged a complaint with the U I Human Rights Commitlee against the Australian government, alleging that it had violated their civil and political rights with its policies regarding climate change. The Committee has not vet issued an opinion on the matter.

亿 Some of the most important cases include: Urgenda Foundation v. The Vetherlands, in the Vetherlands, or Salamanca Mancera v. Presidencia de la República de Colombia, in Colombia. Both the appeals court in The IIague and the Colombian Supreme Court clearly acknowledged the infringement of the plaintiffs' human rights due to climate change caused or partially fuelled by the policies of their respective governments. In the U rgenda case, although the plaintiffs posed the question of the impacts of the government's policies on future generations or persons beyond the country's borders, the court ultimately decided that as "U regenda's claim is alreads admissible insofar as it acts on behalf of current generations of Dutch nationals or" people under the jurisdiction of the Vetherlands" the state did not have an interest in this ground of appeal and, therefore, the Court did not need to consider the issue. I rgenda Foundation el al.v. The Slate of the Velherlands (Ministry of Infrastructure and the Environment), The IIague District Court, Judgment, C og 4.56689 II 1 Z \ 13-1396, 24. June 2015, at \$37. Salamanca Mancera el al. v. Presidencia de la República de Colombia el al., Corte Suprema de Justicia de Colombia, $\mathbf{X}^{0}$ noor2203 ooo 2018 o0319 or, 5 April 2018. For an analysis of the extraterritorial issue in two cases filed in Vorway and Sweden, see: P. de Vilchez Moragues, Extraterritoriality and judicial review of state policies on global warming: Some reflections following the 2016 Scandinavian climate lawsuits', 3 4 RevislaElectrónica de EsludiosInlernacionales (2017) I 27 |doi: 10.17103 reei.34.03|.

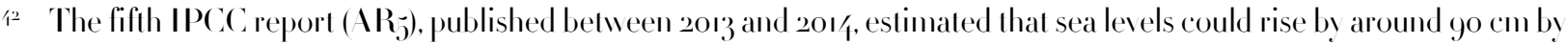
the end of the century. Supra n. 35, at II, 13 and i6. More recent studies suggest that the rise could be even greater. See, for instance, J.L. Bamber el al., 'Ice sheet contributions to future sea-level rise from structured expert judgment', II6(23) Proceedings of the Nalional Academy of Sciences of the Uniled Slates of America (2019), 11195 11200 |doi: 10.1073 pnas.18 $87205116 \mid$.

13.3 For a delailed and rigorous sluds of the issue, see: A. Torres Camprubí, Stalehood under II aler: Challenges of Sea-Level Rise to the Continuily of Pacific Island Slates (Brill, Leiden, 2016) |doi: 10.1163/978900/3216ı1. 
the international climate fora, ${ }^{\text {inat }}$ the end of the first decade of the $21^{\text {st }}$ century and the start of the second, some States from the region seriously considered filing a complaint with the International Court of Justice (IC.J). The idea seemed to have been put on hold given the risk of a decision contrary to their interests, but it would seem that the inability of the international community to provide an adequate response to climate change has led some countries threatened by the sea-level rise to consider again the possibility of submitling such a claim. ${ }^{6}$ Additionally, given the more than likely rise in the sea level, some of these countries have considered purchasing land in other states to have somewhere to resettle their population

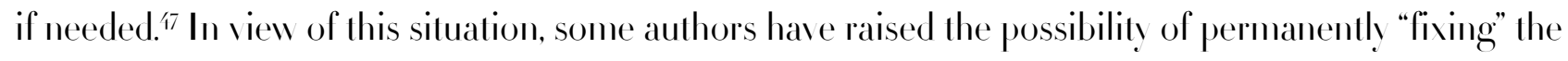
maritime zones over which these States exercise some type of sovereignty (especially the EEZ), so as to ensure that they are not modified even if the istands which conform their territorial basis disappear, thus allowing these States to retain some form of jurisdiction and income, even in an extremely fragile situation. ${ }^{8}$

\section{(4) Climate Change as a Factor Driving Migration Flows}

In light of the various factors discussed thus far, it is to be expected that the inhabitants of these Pacific island States, as well as others that will be hit especially hard by climate change in vulnerable regions of Africa, Asia and the Americas (it must be recalled that the effects of climate change will be especially harsh for the poorest populations), will be displaced to other countries in search of minimum living conditions.99

伯 A. Pigrau, 'Calentamiento global, elevación del mar y pequeños eslados insulares y archipelágicos: un test de justicia climática', in G. A. Oanta (coordinadora), El Derecho del War y las personas y grupos vulnerables (Bosch Editor 2018), at 25j27 .

4. Ibid., at $2 y^{2-2} y^{2}$. For a detailed analysis of this issue, see: C. Voigt, The potential roles of the IC.J in climate changerelated claims', in D. A. Farber and M. Peeters (eds), supra n. 21, at ־ $5^{2-166 .}$

$4^{6}$ See, among others, D. I Prugmand, 'Pacific Islands Group Pushes for International Court Ruling on Climate and I Iuman Rights', Climale Liability Vews, 13 Jugust 201g, or T. Stephens, 'See vou in court? A rising tide of international climate litigation', The Inlerpreler, 30 October 20Ig. Remarkably, more than forty prestigious scholars in the area of international and environmental law have publicly given support to an initiative by students from the Pacific Islands to bring such a case to the IC.J. Among the signatories, there are distinguished scholars from all around the world, like professors Philippe Sands, Jacqueline Peel, Michael Gerrard, Douglas Kysar or Jorge E. Viñuales, to name a few. See Ilarvard, Cambridge, Yale, Welbourne, Auckland, Sydnev Law Academics Support ISP Students' Call to Take Climale Change lo the IC.J. Pacific Climate Resistance, u lugusi 2019.

i7 In 201/, the country of Kiribati purchased 2,000 ha of land in the Fiji Islands. Supra n. 13, at so7.

is Ibid., at log, II2-11/. See also: M.B. Gerrard, 'Maritime Boundaries, Sea Level Rise and Climate Justice', Climate Law Blog, Sabin Center for Climate Change Law, 2 J March 2019 , accessed 9 July 2019.

99 According to the IPCC.s AR , "Climate change over the $21^{\text {st }}$ century is projected to increase displacement of people (medium evidence, high agreement). Displacement risk increases when populations that lack the resources for planned migration experience higher exposure to extreme weather events, in both rural and urban areas, particularly in developing countries with low income. Expanding opportunities for mobility can reduce vulnerability for such populations. Changes in migration patterns can be responses to both extreme weather events and longer-term climate variability and change, and migration can also be an effective adaptation strategv. There is low confidence in quantitative projections of changes in mobility, due to its complex, multi-causal nature. |9.3, 12.1, 19.4, 22.3, 25.9|." C.B. Field el al.(eds), IPCC: Climale Change 2or/: Impacls, Idaplation, and I ulnerability. Part A: Global and Secloral Aspects. Contribution of II orking Croup II to the Fifih 1ssessment Report of the Inlergovernmenlal Panel on Climale Change (Cambridge Iniversity Press, Cambridge, U nited Kingdom and Vew York, 201/), at 73. Additionally, recent studies show that, between ig8o and 2015 , climate change had a greater impact on migratory movements towards OECD countries than income or political freedoms in the country of origin. I). Wesselbaum 
They are what is known as climate migrants or climate refugees. Beyond the question of how to designate them, these migratory movements pose a whole series of challenges, ranging from the humanitarian problems these people suffer to identifing the most suitable legal regime to ensure their protection..$^{50}$ Additionally, the potential impact of these migratory movements on other States' border sy stems is worth examining, especially in the current context, marked by the gradual pullback of many industrialized countries, in the form of the growing construction of walls separating countries of the global north and south.j' Given the fragility shown by Europe's political systems in the face of the arrival of refugees from the war in Syria, with their increasingly restrictive migration and asylum policies and the rise in xenophobic discourse and actions, it is worth asking whether the current system will be able to cope with the more than likely increase in migration flows caused by climate change.

\section{(j) ATransnational Legal Conversation in the Context of Climate Litigation}

Finally, it is worth noting that, in the context of the growing trend towards climate litigation at the national level against State action or inaction, the proliferation of complaints around the world is based on, but also encourages, a fruitful legal exchange (dialogue) that transcends national borders and legal systems (common law, civil law, mixed systems). Indeed, it lakes place between both the lawyers of the various parties (with the creation of global support networks) ${ }^{52}$ and, perhaps more surprisingly, and also more importantly from a legal point of view, between courts from different countries. ${ }^{33}$ The extent to which this exchange can give rise to the emergence of common interpretations or even legal "loans” in the emerging field of State (and corporate) responsibility in relation to climate change remains to be seen.

\section{(E) CO\CLUSION}

and A. Aburn, 'Gone with the wind: International migration', 178 Global and Planelary Change (2019) 96 -109 |doi: 10.1016 J.GLOPL ACII 1.2019.04.0o8|. Furthermore, according to a recent World Bank report, by 2050, there could be 1/40 million internal climate migrants in sub-Saharan Africa, Latin America and South Asia. K. Rigaud el al., Groundswell: Preparing for Inlernal Climale Vigration (The World Bank, Washington DC, 2018).

50 See, forexample, B. Felipe, 'U na propuesta de marco de protección jurílica para las migraciones climáticas forzadas de carácter internacional', in R. Giles Carnero (ed), Desafios de la acción jurídica inlernacional y europea frenle al cambio climálico (Atelier, Barcelona, 2018) at 33-31-3.

5' The most significant example would be the wall between the US and Mexico promoted by the Trump administration, but other important walls have also been built in recent decades, such as the wall between Israel and the Palestinian Territories, the wall between India and Pakistan, or the wall built by the Moroccan authorities that divides the IVestern Sahara in two. At the conference at which the paper on which this article is based was presented, several authors referred to these cases in de tail. See, for instance, the contribution by Dr Salinas de Frías in this same volume of the Spanish Yearbook of Inlernational Law.

$5^{2}$ Here one could cite, for instance, the Climate Litigation Vetwork, promoted by the U rgenda Foundation, or the support work carried out by the US YGO Our Children's Trust with youth organizations from other countries seeking to undertake legal actions to demand greater commitment on the part of their governments.

33 For example, in Juliana v. The US, Judge Coffin expressly referred to the first-instance judgment in U rgenda, delivered by the District Court of The Ilague. Juliana el al.v. The I niled Stales of Imerica el al., District Court of Oregon Vo. 6:15-cvoı 17-TC, Order and Findings d Recommendalion, 8 April 2016, at u.In the case Sarah Thomson v. The Vinisler for Climale Change Issues, in New Zealand, the judge provided a detailed analy sis of five cases from four different countries ( Vassachusells v. EP 1, Juliana v. The US, Friends of the Earlh v. Canada, Client Earlh v. Secrelary of Slate, Urgenda v. The Nelherlands).Sarah Lorraine Thomson v. Ihe Vinisler for Climale Change Issues, Iligh Court of Xew Zealand, W ellington Registry, Decision, CIN 2015-48 $\left.85^{-919}\right|_{2017}$ IZIIC 733, 2 November 2017, al \$\$10 
This article has offered a concise overview of how climate change is generating a series of tensions around the traditional concept of border, not only because the emissions responsible for global warming originate in multiple countries and have impacts that gowell beyond the territorial space in which they are generated, but also because climate change affects fundamental notions, categories and principles of international law, which, since the $17^{\text {th }}$ century, has been primarily based on the notion of sovereign States. In fact, the current legal system developed to tackle climate change, as reflected in the recent Paris Agreement, is based on States' latitude to set their own targets at the national level. Thus far, at least, this system has failed to generate the level of commitment needed to achieve the scientifically defined emission levels that would make it possible to meet the temperature target set in the Agreement itself.

Whether due to the violation of basic principles such as the no-harm rule or the principle of prevention, because the decisions taken in one country impact the enjoyment of human rights in others, because of the erosion this causes on the very notion of sovereignty due to rising sea levels, because of the migrations that it fuels and intensifies, or because of the transnational legal dialogue it is generating in the context of the global climate litigation movement, climate change is a disruptive factor with regard to the nation state's essential nature as the backbone of contemporary international society and the resulting legal system.

In the face of a challenge of these dimensions and characteristics, there is a clear need to advance towards a transformation of international law that moves beyond the current overly State-centric vision and replaces it not with an anthropocentric vision, in which human beings are protected as the fundamental legal interest of that system, but an eco-centric one that recognizes the balance of natural systems —essential to ensure the life of both humans and all other living beings on the planet-as a fundamental pillar of the $21^{\text {st }}$ century legal order. 